\title{
Conflicts and Conflict Resolution in the Horn of Africa: Toward the Study of Regional Peace and Security1
}

\author{
Tafesse Olika*
}

\begin{abstract}
The article attempts to provide an understanding of the phenomenon of conflict in the Horn of Africa. It identifies and dicusses the political factor as the root cause of the problem of peace and security in the subregion. The paper does not argue that thee is a gap of literature on the conflicts in the Horn of Africa. The argument it is trying to present is taht many of the works on the subject taht the author has consulted and reviewed concentrate on conflict markers such as ethnicity, region, religion, etc. This way of understanding of the source of conflicts has the effect of obscuring the primacy of politics as a major root cause of the problem. The approach of academic resaerch on the conflict problematic must not be based on the horizontal and asymmetrical society-society relations; but rather on the asymmetrical and undemocartic state-society relations. Based on this, the conclusion of the article, as the scenarios in the conclusion clearly illustrate, is taht in conflict studies giving little or no attention to the role of state and its institutions as a amjor root cause to conflicts and instabilitieswithin and between states in the Horn of Africa would make it difficult to suggest practical/realistic copping strategies of dealing with the problem of peace and security in the subregion.
\end{abstract}

Key words: conflict, conflict interlinkage, conflict resolution, peace, security, democracy, governance

\section{Introduction}

Things of positive value seldom come out of scholarly literature or media reports on the Horn Africa. The sub-region has always been associated with crises of farreaching consequences. Often reported about the Horn of Africa have been intra-

\footnotetext{
${ }^{1}$ This is an updated version of a paper written and presented at Institute of Political Science of the University of Leipzig (Germany), where the author stayed as DAAD research fellow from November 2001 to January 2002.

* Lecturer, Department of Political Science and International Relations, Addis Ababa University
} 
state and inter-state conflicts, recurrent drought and hunger or a socio-economic and political crises. Although the colonial legacy is often cited as responsible, the cause for the persistent lack of security in the Horn of Africa lies in the socioeconomic and political policies of the post-colonial regimes. The sub-region has passed through several devastating civil and inter-state disputes and violent conflicts/wars, which in some cases are yet to be settled. These have consumed considerable human life and material resources, political energies and policy attentions of political leaders of the states of the sub-region. Significant resources have been diverted from development endeavours to war efforts. Needless to say, the prevalence of constant and continuous instability and insecurity has made the Horn of Africa one of the world's peripheries economically, socially and politically.

On the other hand, the conflicts and instabilities in the Horn of Africa have not attracted serious scholarship with regard to their root causes. Although there is no shortage of literature on the conflicts in the sub-region, many of the works do not explain their root causes systematically. While some studies emphasize religion, others underline resources, ethnicity, or politics. Needless to say, since the end of the Cold War debates on issues of conflict in general and the Horn of Africa in particular tend to emphasize ethnicity. While ethnicity as a factor of conflict can not be denied, the trend to overstate it, however, has the implication of obscuring the primacy of politics, i.e. the role of state which is at the centre of the contemporary conflicts that rock the sub-region.

Peace and security study is not only about the existence or non-existence of war, but it, more importantly, is about economic security, mental/psychological peace and political and economic freedom of the people at both national and regional levels. What follows from this is that peace and security study is about democratizing the structures, institutions and operations of the state.

The aim of this paper is to outline the causes of the conflict and insecurity in the Horn of Africa and suggest intra and inter-state conflict resolution strategies with a view of provoking further research on the subject. Main beneficiaries of this study are, thus, the academics, researchers in the field, consultants, policy analysts, and students interested in peace and security studies.

\section{Background}

The Horn of Africa both as a political concept and a physical entity does not lend itself for precise definition. The geographical extent of the sub-region and the number of countries that it consists of and thus its political map keep on perpetually changing. Conventionally, the Horn of Africa is understood as the area that comprises Ethiopia, Somalia, Djibouti, and Eritrea (after its partition from Ethiopia in 1991), and these are sometimes referred to as "core countries" (Mesfin, 
1999). When political, economic, and cultural factors are taken into consideration, Kenya and Sudan can be added to the list. Furthermore, the spillover of the political-economy of conflicts also extends the political map of the sub-region to other countries. The best example of this is Uganda's accession to the InterGovernmental Authority for Development (IGAD), a regional organization established in 1986 with its headquarters in Djibouti. Egypt, a North African country, also is not less involved in the affairs of the Horn of Africa because of the factor of the Nile. The US's "Greater Horn of Africa Initiative”, launched after the end of the cold-war also extends the region to the 'Great Lakes' region.

The focus of this paper is the 'core countries', and Kenya and the Sudan. This is because of the fact that these countries have many things in common and whatever development takes place in each of them affects all others directly or indirectly. As Markakis (1998:5) has observed, the Horn is not only a geographic designation, but also a cultural and socio-economic entity and this is what makes it distinguishable from the adjacent regions. Yet, this does not mean that these states do not have differences. They differ, inter alia, in terms of level of economic development, territory and population size, human and natural resource base, regime ideology, state structure and political system. And sadly enough, the regional behavior of the states of the Horn have, more often than not, reflected these differences rather than the similarities.

\section{The Horn as a Cultural and Economic Zone}

The Horn countries geographically, economically, and culturally form an interconnected unit. As I have argued elsewhere the Horn of Africa forms "a cultural and economic zone" (Tafesse, 1998). Markakis (1998: 5) substantiates this by saying that the Horn is 'a region with a multitude of physical, social, cultural, economic and other integrating features'.

Socio-culturally, constant intercourse/interactions (both in peace and war) brought the peoples of the sub-region closer together. Many population groups of the Horn countries have mixed origins, speak related languages, and have close cultural and economic ties. The states of the Horn, except Ethiopia, are the result of the decolonization process in Africa in the post-Second World War period. In other words, the modern state system in the Horn of Africa, like in the rest of the continent, emerged in the political boundaries that were carved by the former colonial powers dividing peoples of the same ethnocultural groups into different political/legal jurisdiction. This has resulted in the existing complex ties across boundaries among the citizens of the states in the Horn. For instance, the Afar people are divided between Ethiopia, Djibouti, and Eritrea. Tigrai speaking people straddle Ethio-Eritrean border. Similarly, Somali speaking peoples are divided between Ethiopia, Djibouti, Somalia and Kenya. Ethiopia and Kenya share the 
Oromo ethnic group. Furthermore, several other different population groups also span Kenya-Sudan, Ethiopia-Sudan, and Eritrea-Sudan frontiers. In general, the countries of the Horn of Africa that have common borders also share, at least, one group of people who claim to belong to the same language, religion, culture and mode of economic activity.

Topographically, the Horn of Africa forms highlands, lowlands and highlandlowland transition zones, each playing important role in many respects. While highlands are sources of rivers and areas of settled agriculture, the lowland areas are predominantly characterized by pastoralist mode of production, where livestock raising is the major economic activity. The highland-lowland interaction zones form a dynamic transition not only of people's mode of life-sustaining activities but also of natural resources and population migrations. Thus, there is intensified exchange of products and common use of shared natural resources. Such interactions are not, however, always peaceful as the shared resources are scarce on one hand and there are, unfortunately, no agreed upon rules and regulations of resource sharing on the other. Moreover, the fact that the Horn of Africa is situated in the geoponics of the Nile Valley, the Red Sea and the Indian Ocean has given it strategic importance, making it one of the scenes that always attract foreign powers colliding and colluding among themselves to establish hegemony.

Economically, the sub-region represents a natural economic zone. Generally speaking, the Horn is a region of resource scarcity which the growth of population and the worsening environmental degradation further aggravate. Though there are, of course, variations among states of the sub-region in terms of resource endowment, taken as a whole however, there are considerably sufficient resource potential (both human and economic) that could be developed and utilized for mutual interest; realization of this, however, requires peaceful and cooperative relationships within and between the countries of the Horn of Africa sub-region. Lack of cooperation in the utilization of the available potential resources, such as grazing lands, rivers, and seaports, has rendered nearly all countries of the subregion to be among the poorest economies of the world. Environmental degradation and vulnerability to recurrent drought and hunger, accompanied by lack of agreed upon policies for resource use and management resulted in food insecurity and conflicts. The states of the Horn are share problems of conflict and poverty, and also whose opportunities of development are closely interlinked.

\section{The state of conflict in the Horn of Africa}

To reiterate, the Horn is a sub-region of protracted conflicts and instability. Over the past six decades there was no single year when the sub-region had been free from conflict, be it intra-state or inter-state. What distinguishes the Horn of Africa 
is the fact that it has hosted the longest civil wars in Africa: the civil war in Ethiopia and the Sudan. In Ethiopia, the civil war between the central government and the Eritrean secessionists ran for 30 years (1961-1991). The North-South conflict in the Sudan that began after the country's independence in 1956 continued until very recently, with only a ten-year period of détente (1972-1983) achieved through the Addis Ababa Peace Accord, brokered by Emperor Haile Selassie. Resumed in 1983 because of policies of the Nimeiri regime, the NorthSouth conflict in the Sudan continued until 2005 when the Compressive Peace Agreement (CPA) was signed between the government and the mainstream Sudanese People's Liberation Movement (SPLM). On the bases of the CPA the Southern Sudanese held referendum in January 2011 in which, according to the referendum commission's temporary report, $99.57 \%$ voted for the independence of Southern Sudan. The final fate of the result of the referendum and the implications of separation of the Sudan into two sovereign states for the politics of the Sudan and the region at large remains to be a new serious cause of concern.

The condition in Somalia is much different. The post-colonial Somali state, which emerged with the merger of the former British and Italian Somalilands in 1960, has collapsed with subsequent diffusion of power among various warlords that continue fighting for control of resources. What is unique about the conflict in the post-1991 Somalia is the fact that it is among several clan based warlords, to which the central government is not a party: Somalia does not have any effective central government since 1991. The conflict is among several clan based warlords. The reason for the continuity of statelessness and instability in Somalia lies in the fact that the contending warlords could not cooperate to form a central government by consent, nor could one of the warlord groups assert power and dictate its will upon the others to the effect of creating a central authority. The Djibouti sponsored Arta conference that established a transitional government for Somalia could not last because it lacked legitimacy at home (because it was not all inclusive) and encountered unfavorable sub-regional environment. The Nairobi Peace-Process succeeded in persuading all Somali factions to form a joint parliament in exile for which the daunting task ahead has also been how to form a unity Government of Somalia. This difficulty was evidenced by the war between the Union of Islamic Courts (UIC) supported by international terrorism and the Transitional Federal Government (TFG) of Somalia supported by Ethiopia, which had militarily intervened in Somalia from 2006-2009.

What is evident from the above discussion is that after the end of the cold-war Somalia and the Sudan became the epicenter of conflict in the Horn. This does not, however, mean that the other Horn states have been spared off conflicts in the post-cold war era. Ethiopia and Eritrea crossed swords from 1998-2000 (Tekeste and Tronvoll, 2000). No matter what the differences in the degree of intensity, 
nearly all of the states of the subregion have been fighting with their domestic opposition. Djibouti has not been able to solve its delicate ethnic political balance; feeling being marginalized, the ethnic Afar has always been pressing the Issadominated government for equitable share of power in an open political space. The Afar dissatisfaction in Djibouti led to civil war in the 1990s and this was not settled until the 2001 peace accord reached between the Afar based Front for Restoration of Unity and Democracy (FRUD) and the Government of Djibouti. The government of the youngest state of Eritrea, under the sole control of the de jure one-party (EPLF, renamed 'the Peoples' Front for Democracy and Justice/PFDJ in 1994)' is highly vulnerable to social and political conflicts. Eritrea's military defeat in the 1998-2000 Ethio-Eritrean war (Tekeste and Tronvoll, 2000) also has significantly eroded the PFDJ regime's legitimacy based on mere 'libratory ideology'.

Since the 1990s, Ethiopia has been experimenting with ethnic federalism and multiparty democracy. The EPRDF-led government has restructured the Ethiopian state dividing it into nine self-governing regions on language and ethnic criteria. A plethora of political parties, the majority of which are based on ethnic constituencies, have also emerged. The policy of restructuring the country along ethnic federalism, as the regime and the proponents of the policy argue, has been sought as a solution to the country's outstanding problems of conflict. But, although there have been mixed evaluations from different angles, both the ethnic federal structure and the multiparty system are not working fairly well in this regard. Even though there has not been any acknowledged open military conflict in Ethiopia since 1991, the instituted federal structure has yet to provide the country with a measure of political stability. Differently put, despite the institutionalization of ethnicity as state structure and as a political party organizing factor, still there are dissatisfied ethnic-based opposition movements demanding either for a more open political-space, if in effect not for exit.

Kenya, though appeared to be an island of stability, has not been spared off conflict in the sub-region. As Oyugi (2001:32) points out, it has experienced leftright ideological polarization, secessionist tendencies, and ethnic conflicts. In fact, compared to many of the post-colonial states in Africa, Kenya witnessed regime stability, save the recent post-election violence. In spite of the phenomenon of lifepresidency, Kenya is one of the few African countries that were not affected by coups d'etat (military or civilian), once considered as a dominant mode of regime change in the continent. Only two acknowledged coup attempts were reported in Kenya: in 1971 and in 1982. Kenya's relative tranquility is not because it has a democratic system of administration. The regimes of President Jomo Kenyatta and his successor Daniel Arap Moi were authoritarian. Until recently, the Kenyan African National Union (KANU), the de jure single-party, dominated the country's 
political scene. This significantly negatively influenced state-society relations in the country. Kenya also has been the only consistently pro-Western nation in the Horn of Africa. In its domestic and foreign policies, Kenya had never shifted positions between the cold-war ideological and military blocs. The West's security assistance and the authoritarian regimes' ability to establish tight control over the society were the factors for Kenya's relative stability.

However, since the early 1980s Kenya has been no less chaotic than the other countries of the Horn. Particularly after the 1982 coup attempt, the Moi regime's increasing centralization of power for fear of insecurity and, corruption of government officials, unemployment, and the politicization of ethnicity has changed Kenya's political landscape (Oyugi, 2001:32). Social violence - banditry, hijacking, robbery, murder, etc. - in urban areas and government's discriminatory rural land policy incited conflicts in Kenya. The spillover effects of the conflicts in the region also affected the country. Hundreds of thousands of refugees produced by conflicts within and between neighbouring countries not only created social and economic problems, but also political and security concerns for Kenya (Khadiagala and Lyons, 2001:108). And since the 1990s Kenya is one of the target countries of international terrorism in eastern Africa.

\section{Causes of Conflicts in the Horn: Against the Conventional Understanding}

Peace and security studies need clear and correct understanding of the underlying causes of conflicts. Correct understanding of core issues at stake for parties in conflict enables students of peace and security studies to suggest realistic strategies/mechanisms of conflict resolution and post-conflict peace management. In view of this, although the issue of conflict in the Horn of Africa has significantly attracted scholarship, much of the literature on the subject have not systematically addressed and explained the root causes of the conflicts. In short, there exists a lacuna in terms of clear and careful understanding of the origin of the conflicts within and between states of the sub-region. Ethnicity, religion, region, border disputes, scarce resources, or armed struggle for state power have been held as factors responsible for the conflicts in the Horn. For example, John Markakis, one of the observers of the affairs of the Horn of Africa, has authored, co-authored, or edited several books on conflicts in the Horn of Africa under different titles in the 1980s and 1990s.

The traditional notion of security is to relate it with the prevalence or absence of armed conflict in society or between societies. This view aside, the purpose here is to understand the political economy of security that underpins the role of the state and its institutions. In other words, security is inseparable from the issue of democracy and development (Jinadu 2000: 4). While bringing the role of the state 
into the focus of his analysis he then notes that the absence of peace and security in Africa occurs when the state fails to perform its 'sovereign responsibility' (Jinadu (2000: 2; Deng et.al. 1996) of mediating the "[s]tructurally induced and institutionalized inequalities". The conclusion Jinadu (2000: 2) makes is that "...the problem of peace and security in Africa is bound up with the nature and character of the modern state and its role and position in the national and international society." Simply put, insecurity is a condition where the state as an institution for mediating conflicts does not perform enough its responsibility but instead engages in hegemonic drives for personal or group interest. Hence, the search for security in society as well as between societies must not be conceived of apart from taking into account the nature of the state and the role of its institutions. Therefore, it is not with mere coincidence that scholars on the subject suggest that sovereignty need to be redefined (Deng et.al. 1996).

It seems that the literature on the issue of peace and security in the Horn of Africa has been influenced by the winds of global political change: the end of the Cold-War and the disintegration of the Soviet Union. Following the disintegration of the Soviet Empire and its East European socialist allies that led to the birth of a number of ethnic-based states, the general tendency of scholarship is to make ethnicity central to the discourse on the issue of instability in the developing parts of the world. This has significantly obscured the root cause of conflicts that plague many regions of the world. The Horn of Africa is not an exception. Conflicts have been fought in the sub-region under the name of nation/nationality, ethnicity, region, religion, or classes. But, in the light of the argument this author is making, these are manifestations or triggering factors, not the root causes of the conflicts. As Markakis (1998) notes, "the state is the cause, the bearer of ultimate responsibility for outbreak of conflicts in two important ways: competition for resources under the condition of great scarcity, and control of the allocation and monopoly use of the scarce resources”. This passage underscores the fact that politics is the major cause of the conflicts, regardless of the form of their manifestations.

Mesfin (1999) asserts that the major conflicts in the Horn have not been fought horizontally between different ethnic or religious groups. They are rather politically motivated clashes between the state and society. As Markakis (1998) sunccintly puts, it is the outcome of incompatible interests in which the State and other actors that fight for its control are involved. To be more precise, while politics is the ultimate cause, ethnicity and religion are factors of mass moblization that are given prominence by the disgruntled political elites fighting against what Elsenhans (1996) calls the "state classes". For example, despite ethnic and religious homogeneity of the Somali society, what has transpired in the post-1991 
is the bloodiest conflict that ultimately led to State collapse and disintegration of that country.

Ethnicity and religion feature prominently as the cause of conflict particularly where disparity in the share and control of national resources (political power and economy) correspond to ethnic and/or religious differences. From this point of view, while de-emphasizing the role of ethnicity and religion in conflict may be a risky exercise, over-emphasizing it would also create the risk of reducing the problem of conflict to the existence of ethnic and/or religious diversity per se. Both will have implications for conflict management and resolution efforts. Why has, ethnic diversity in the industrialized (developed) countries, for instance, not come out as a source of conflict? Why however 'semi-peripheral' countries of Europe like Spain under Franco's rule experienced conflict that followed regional or ethnic fault lines? And why has this conflict lost much relevance and Spain transited to devolution and federal democratic welfare state in the post-Franco period? (Mangen 2001: 138). This clearly illustrates the political economy of conflict in a given society. Anywhere, ethnicity, religion, and other markers of group identity become a factor of conflict when political actors manipulate them as tools to mobilize people in the pursuit of specific political or economic ends.

Elsenhans (1993:12) argues, "The ascendancy of religion as a political resource is the combined result of disappointment of the lower classes with the Western ideas (Revolution, Socialism, Statism)". Particularly with the disintegration of the Soviet Union and the collapse of communism, competing political elites (both wielders of state power and those in opposition) in the Third World are devoid of populist ideology. Liberalism has also declined in importance due to the weakness of the state to perform well in the realm of governance, the abuse of the cardinal principles of modern democracy by the ruling elite. Hence, there is no surprise if the discontented political classes have resorted to religion and/or ethnicity as an ideology of mass mobilization. In short, religion and ethnicity are brought to the fore as political instrument for political elite struggling to capture state power, the source of wealth, as well as social status.

Difference in religion as an ideology also does not matter much in forging political alliance. For instance, the Mengistu regime in Ethiopia supported Somali insurgent groups against President Siad Barre’s government before 1988, when the two authoritarian regimes signed an accord in which they vowed not to support each other's dissident groups. The Islamic government of Sudan has been supporting the Lords' Resistance Army (LRA), a Christian insurgent group fighting against the government of Uganda as a tit-for-tat policy, viz. to counter the Ugandan government's support of the SPLM/A. Several anti-government movements in the Horn of Africa that have ethnicity and religion as political agenda have also forged alliances that cross-cut religious and ethnic boundary lines 
as part of their efforts to destabilize and weaken the regimes they fight against. In short, conflicts in the Horn cannot be defined in terms of "clash of civilizations", to use Samuel Huntington's most criticized phrase.

As mentioned above, the Horn is a sub-region of cultural-mix whose peoples share several characteristics. There is no significant disparity in socio-economic development among the peoples of the sub-region. For example, it has been very common to explain the north-south conflict in the Sudan in racial and religious terms. It must be admitted that the development disparities between Northern and Southern Sudan - set in motion by the British colonial power as part of its divideand-rule policy - coincided with ethnic, religious, and regional differences. It must, however, be noted that the root of the north-south conflict that ran for three decades (1956-2005), with of course 10 years interlude (1972-1983) as the result of Addis Ababa Agreement mediated by Emperor Haile Selassie, is the disparity in terms of access to state power and economic resources between the Northern and Southern political elites in the post-independence period. Similarly, the problem in Somalia, with its origin in the crisis of state-building process under the postindependence Somali regimes, is the rivalry among different clan-based warlord factions for hegemony over economic resources for selfish interests. As Medhane (2002; 2004) contends, 'control of land, ports, local markets, and export trade has been the bone of contention among the warlords in Somalia.' Adewoye's (2000: 39) observation further advances this line of argument. He writes,

[W]hilst the African predicament is often expressed in economic terms, it is really little more than "suprastructural” problem, grave as it has been. Africa's crisis lies mainly in the political domain, in the structural sector from where poor or bad leadership often reflects adversely in all other sectors and facets of the political system and society.

This logic of political-economy can also apply to explain inter-state conflicts in the Horn of Africa. As international borders in Africa are so artificial and so erratic, any state that wishes to create conflict with any of its neighboring states could use the border issue as a pretext. Border disputes that developed into full-scale interstate wars, however, have been very rare in Africa. In the context of the Horn, inter-state frontiers were delineated, but not demarcated, through agreements between Ethiopia and the former colonial powers - Britain, France and Italy. Here also overt efforts of armed forces of one state to invade the territory of another only have happened between Somalia and Ethiopia, and recently between Eritrea and Ethiopia.

Even though they were fought under the name of 'nationalism' or 'border disputes', these wars have economic and political roots. Somalia's drive in the 
1960s and 1970s for "unification" of Somali-speaking peoples in the Horn of Africa was mainly spearheaded against the Ogaden region of Ethiopia. This was because the Ogaden, compared to Somalia, is better endowed with land and water resources that are necessary for sustainability of pastoralism, the main economic activity of the Somali people. The Ogaden is also said to be potentially rich in oil resources. The Juba, Ghenalle, and Wabi Shebelle rivers - all with their sources in eastern Ethiopian highlands - that provide Somalia with water all the year round traverse the Ogaden region. The only area where cultivation is practiced and has potential for irrigated agricultural development in southern Somalia is between the Juba and Wabi Shebelle rivers (Touval, 1963). As Laitin and Samatar lamented,

If there are indeed major resources of oil in disputed territories, the issue of nationality of the nomads will pale to insignificance and the issue of military power to control the area will take precedence (Laitin and Samatar 1984: 34).

In view of the hegemonic drive of the Somali state for resource control through annexing the Ogaden, the Somalis of the region were simply the pawn of this expansionist policy of the Somali state. In the same token, while Eritrea's 1998 invasion of Badme and its environs was driven by the ambitious policy of making Eritrea "the Singapore" of the Horn of Africa by the Issayas regime, the border issue was a passport to realize this policy.

To recapitulate, conflicts in the Horn Africa are the result of bad political policies and praxis. The institution that is responsible for this is the state. Precisely speaking, the 'state class' that controls the government of the country in its zeal to accumulate and control economic resources is the prime source of conflicts and insecurity in the Horn. As Markakis has put:

Since those who control the state have used its power to defend their own privileged position, the state has become both the object of conflict and the principal means by which it is waged. Dissident groups seek to restructure the state in order to gain access to its power, or failing that, to gain autonomy or independence. The ultimate goal of most parties to the conflict, of course, is to enlarge their share of resources commanded by the state. This is the real bone of contention and root causes of the conflict in the Horn, whether it is fought in the name of nation, region, religion, ethnicity, or clanship (Markakis, 1994: 217-8).

Hence, there is "a clear correlation between exclusion from state power, reduced access to resources and the incidence of conflict” (Markakis, 1998:5). Those who 
control the state power and the dissidents see the state as a "prize" to be won for it is the basis for accumulation of wealth and patronage that can establish and maintain a political base (Cliffe, 1999, 14). In the Horn of Africa, as both the wielders of state power and those who fight for it perceive politics as a zero-sum game, competition over the state power and economic resources is not amenable to compromise. The drive for gaining and retaining state power is always through the force of arms, what Samatar (1988: 157) calls "primitive rebellions, based on generic dislike for the existing order”. In sum, the core cause of conflict, fought at whatever level and degree of intensity is violent competition over irrationally managed and inequitably distributed national resources. Conflict in the Horn of Africa is the result of government policy failure.

\section{The Horn of Africa Conflict Inter-Linkage}

As government policies and practices bear the ultimate responsibility for conflicts in the Horn of Africa, nearly all the conflicts in the sub-region have internal origin: their sources lay in domestic political and economic issues. Conflicts within and between states in the sub-region are interconnected and, thus, have to be studied at broader regional context. The regional context, according to Deng, shapes their dynamics and influences the prospects for their management and resolution (Deng, 1996:131). In the Horn of Africa, intra-state conflicts are just like a moving cyclone with significant repercussion at regional level. This means instability at one level has a spillover effect at the other. This in turn means conflict at one level of analysis influences or alters the structure of alliance of forces or actors at the other level. Put differently, while the regional context shapes the course and the outcomes of intra-state conflicts, intra-state conflicts in turn can be transformed into inter-state conflicts. In short, intra-state conflicts infect inter-state politics in the Horn of Africa.

This conflict inter-linkage occurs for several reasons. To start with, in the Horn of Africa, "[w]hether in terms of refugees, arms flows, demonstration effects of nationalism, or as the base from which opposition (including armed insurgency) is organized, neighbors are drawn into internal conflicts” (Deng, 1996: 147). To explain, the Horn of Africa is the "home and destination of refugees", that is, the states of the sub-region are both the producers and recipients of refugees. What must be mentioned here is the fact that refugees and refugee movements in the Horn sub-region are both effects and causes of conflict. The other thing that the refugees with political interests - for that matter, all refugees have political interests as they are products of conflicts/wars caused by bad government policies - organize themselves in countries of asylum and conduct political and military activities against the government of their origin. Hence, in addition to economic 
and social problems they pose to recipient countries, their political and military activities in countries of asylum also provoke inter-state tensions and conflicts.

Another factor for conflict inter-linkage thereby forming regional 'conflict system' has been the pattern of mutual insurgency support by the states of the subregion. This reciprocal insurgency support implies that local politics of the Horn countries have been played at the sub-regional level. In other words, this tit-for-tat policy in the inter-state politics of the Horn has produced a pattern of mutual intervention in the sub-region (Cliffe, 1999), thereby giving conflicts of internal origin a regional character.

The classic example of uneasy inter-state relations as the result of mutual insurgency support has been between Ethiopia and Sudan. Before 1991 the two countries supported each other's opposition movements as a strategy for containing the other's policy of destabilization. This has obstructed the possibility of resolving not only domestic conflicts in the two countries, but also their relationship. Ethiopia and Sudan are countries that experienced the longest civil war in the Horn of Africa. The conflicts in Sudan and Ethiopia also affected the regional politics. Given the domestic authoritarian politics and uneasy inter-state relations, anti-regime movements became the factor to link up the states of the Horn in a common 'security-dilemma', the condition in which the security measure taken by one state is seen as source of insecurity for the others (Cliffe, 1999).

Easy availability of arms through illegal circulation is also an important condition for conflict inter-linkage in the region. If the cold-war superpowers poured military weapons to their respective clients (states or the opposition), the end of the global cold-war politics has not brought about a significant change in the equation. The end of the cold war has resulted in the expansion of sources of military weapons and armed actors. As a post-cold war study on military profile for IGAD countries indicates, the disintegration of the Soviet Union has led to the birth of new states willing to traffic arms to local actors in the developing world. The break-away states of the former Soviet Union such as Georgia, Moldova, Belarus, Ukraine, and Kyrgyzstan have become new sources of arms delivery to the Horn sub-region (Project Ploughshares, 1998/99). This is besides the continuing arms flow from traditional sources. The abundance of arms means the wider the spectrum of forces that use them (United Nations, 1997:86-95).

In a nutshell, conflict inter-linkage has made the Horn of Africa a region of "security complex", where insecurity in a country spills over to the other countries of the sub-region. In the sub-region domestic conflict in one country cannot be explained in isolation from the sub-regional security dilemma. This has presented practical challenges to conflict resolution and post-conflict peace management efforts throughout the second-half of the twentieth century, the effects of which persist to the present. 


\section{Conflict in the Post-Cold War Horn of Africa: Changes and Continuities}

The end of the East-West conflict and the dramatic change in the post-Second World War global order has had implications for the Horn of Africa. Despite the interplay of local, regional and global political and economic dynamics, the transformations that have taken place in the sub-region are contradictory in terms. To start with, the end of the cold-war has led to the loosening of the ideological bonds the Horn states had with their respective superpower patron: the erosion of the source of their strong foreign support. This weakened the authoritarian regimes in the Horn states, thereby altering the dynamics of conflict in the African Horn. With the weakening of the authoritarian regimes some dissident groups that were dissatisfied with the nature of allocation of resources (both economic and political) were able to control state power; some others successfully pressed for exit or greater autonomy using region, religion or ethnicity as instruments for support mobilization. The Horn of Africa in post-cold war era also witnessed both statecollapse (Somalia) and the birth of new states - Eritrea, the Republic of Somaliland, and Southern Sudan.

In Ethiopia and Somalia, insurgency movements ousted the politically, economically and militarily weakened regimes. With the fall of the Said Barre regime, the Somali State collapsed and the southern part, the former Italian colony, was sliced into many unruly clan-based 'fiefdoms' fighting for power and economic resources (Medhane, 2002); and Somaliland, the former British colony, declared its partition. No political and diplomatic efforts towards restoring peace and security in Somalia could bear fruit. None of the warring warlord factions also could impose its will upon others to establish a central authority for Somalia. The Transitional National Government (TNG) - the outcome of the 2000 Arta Conference in Djibouti - could not last long; the existing Transitional Federal Government (TFG) is also not doing well.

The collapse of the Mengistu regime in Ethiopia led to different developments. The TPLF and the EPLF, the rebel forces that ousted the Derg established effective control in Addis Ababa and Asmara respectively. While the EPLF made Eritrea a de facto independent state that became de jure through the referendum held in May 1993, the TPLE-led EPRDF established a transitional government in Ethiopia in July 1991. The EPRDF-led Transitional Government of Ethiopia (TGE) recognized Eritrea's independence. The resolution of Eritrea's problem enabled the EPRDF coalition government to consolidate its rule in Ethiopia, and concentrate on its model of state-building project.

The authoritarian regimes of President Daniel arap Moi and President Gouled in Kenya and Djibouti respectively underwent "self-transformation" to democracy and multiparty politics as the strategy of survival. In the Sudan, however, the 
regime of the National Islamic Front (NIF) remained adamant to its Islamist ideology, and continued pursuing the policy of military solution for the conflict with the Southern Sudanese movements, until the 2005 détente mentioned above.

With regard to inter-state politics, there emerged a phenomenon of détente, as regimes of the states of the sub-region seemed to have committed themselves for peace and cooperation during the first-half of the 1990s. Particularly Ethiopia, Eritrea and Sudan took the lead to take the position of mutual non-interference in each other's "internal affairs" (Cliffe, 1999:3) The most spectacular example is following the rapprochement between Addis Ababa and Khartoum, the EPRDF government closed down SPLM/A's operational bases in Ethiopia. For the SPLM this meant that it out-stayed its welcome by Ethiopia. Regional summits were frequented between Addis Ababa, Asmara, and Khartoum. There also emerged an atmosphere of collaboration to strengthening the Inter-Governmental Authority for Development (IGAD) and assisting the Organization of African Unity (OAU), renamed the African Union (AU) in 2002, in resolving conflicts in the continent. With the euphoria of new office and the need for gaining international legitimacy, and, while competing for regional leadership-role, the government of Ethiopia and Eritrea were among the prime initiators of "the new order" for Africa and the Horn. They also made a series of mediation efforts to resolve the conflicts in the Horn of Africa. This prompted observers of the affairs of the sub-region to characterize the Horn states' mood of the period as,

For the first time for decades - maybe in history - all the countries of the Horn actually do live in peace with each other...Thus there are no more open conflicts between the states (Cliffe, 1999:3).

Thus, seeking peaceful resolution of conflicts in the sub-region, and institutionalizing the attitude of cooperation for mutual security characterized inter-state politics of the first half of the 1990s. This however did not last long; reversal to regional conflict and mutual intervention resumed after 1993. In 1993, Eritrea started accusing Sudan of infiltrating anti-regime forces (namely, the Eritrean Islamic Jihad Movement - EIJM) into Eritrea to destabilize the Asmara regime of President Issayas Afeworki. Sudan on its part accused Eritrea of sponsoring the Sudanese dissidents in Eastern Sudan (Amare Tekle, 1996:505). Relations between the two countries further worsened when Eritrea publicly pledged to support the National Democratic Alliance (NDA), which included various Sudanese opposition forces (Amare Tekle, 1996:506; Horn of Africa Bulletin. 1998: 30). The two countries broke off diplomatic relations and the Sudanese Embassy in Asmara turned to be an office for NDA. The Government of the new Eritrea, as was not consolidated politically and its economy in shambles, 
as still is, entertained fear of insecurity that influenced the country's regional behavior. Asmara developed aggressive and confrontational regional foreign policy that brought it into conflict with its neighbors on both sides of the Red Sea.

The promising start in Ethio-Sudanese relations in the early 1990s, when the two countries showed the gesture of friendship and cooperation and signed a number of agreements to that effect (Sosina, 1994: 7), began to deteriorate. The situation further worsened when Ethiopia accused Sudan of interfering in its internal affairs by supporting Ethiopian dissident movements, most of them, allegedly, with Islamic orientation (Amare, 1996: 506). Ethiopia's fear of threat from Sudan was confirmed by the statement of Hassan el-Turabi, an ideologue of radical Islam. Turabi's statement reads, "Ethiopia will self-destruct in the near future, thus giving the way for the establishment of an Islamic Oromo state and resulting in a chain of Islamic polities extending from Sudan to the Indian Ocean" (Amare, 1996:505). Ethiopia also accused Sudan of complicity in the assassination attempt against Hosni Mubarak, the Egyptian President, in Addis Ababa while he was arriving at Bole International Airport for the June 1995 OAU Summit. Ethiopia demanded the handover of the suspected terrorists to Ethiopia, and took the case to the UN Security Council when Sudan refused the demand. Subsequent developments led to the worsening of the relations of the two countries. The level of diplomatic relations between Khartoum and Addis Ababa was reduced and the number of diplomatic personnel was significantly cut.

Feeling insecure around its border, Ethiopia also argued that there were destabilizing forces operating in Somalia taking the advantage of lack of a central government there. In a hot pursuit of what it perceived the destabilizing forces, Ethiopia also moved to violate the Somali border during the second half of the 1990s. Cross-border anti-government movements caused similar tensions between Ethiopia and Kenya. Ethiopia and Kenya concluded a military pact in 1963 against the five-pointed star of "Greater Somalia” policy and have had remarkably good political relations. Ethio-Kenyan relations were not affected much even during the revolutionary period in Ethiopia.

With the outbreak of Ethio-Eritrean war in 1998, new regional re-alignment of forces began forming. Both Ethiopia and Eritrea sought rapprochement with Sudan. Having been denied access to Assab and Massawa ports, Ethiopia also came closer to Djibouti for port service, if not for classical balance-of-power politics per se. Again with the shift in the pattern of regional alliance, Ethiopia, Sudan and Yemen (from across the Red Sea) entered a tripartite entente, called the Sana'a Forum, in 2002 with, arguably, the intent to contain Eritrea, their common nemesis. The Forum was later joined by Somalia and Djibouti which has created some apprehension on the part of Eritrea, which remains the odd one out in the region. 
In final analysis, the re-emergence of inter-state tensions, a new cycle of mutual insurgency support resurfaced in the Horn of Africa. The north-south conflict in Sudan intensified; and with the obvious assistance from neighbours the southern Sudanese rebel forces succeeded in controlling larger territories in the southern Sudan. The regional conflict system of the cold-war era, which was replaced by a temporary détente, re-emerged. This dashed the hope in the early 1990s to resolve the conflicts in the sub-region in a concerted effort (Kiplagat, 2000).

\section{Conflict Resolution in the Horn of Africa: The Need for a new Approach}

The concept 'conflict resolution' is about the effort to create an environment in which competition over scarce resources and state power would not lead to lethal conflicts. Conflict resolution requires understanding of the root causes of conflicts and putting in place institutions and procedures to forge and foster peaceful relations within and between states. In the Horn, different efforts have been made to manage and resolve conflicts at different times. But all have failed to bring the intended results largely because the attempts have been partly power-centered, and partly based on incorrect understanding of the source of the conflicts. Another outstanding problem has been the propensity to use force by belligerent parties (state vs. state, or state vs. its opposition). As mentioned, most of the time governments of the states of the Horn Africa had been and are authoritarian that arbitrarily used force to resolve local and international conflicts. This has also influenced/shaped the thinking and actions of anti-regime forces in the sub-region.

Besides the political actors' propensity to use force as an instrument of policy, the conflicts in the sub-region, as has been discussed, also have interlinkage. In view of this, conflict resolution and the post-conflict peace and security management in the Horn require a new approach. Attempts at resolving the conflicts in the sub-region have to take place on regional basis, not on the traditional conflict-to-conflict basis. Differently put, resolving the Horn conflict system requires what I would call "peace-system approach”, a regional-system strategy of attaining and sustaining peace and security. This means, as the conflicts in the Horn are interlinked in many complex ways, concentrating only on issue(s) between conflicting/warring parties at a particular level would not lead to enduring solution. Conflict resolution and post-conflict peace management requires an allinclusive approach. Thus, there must be local-regional frameworks for conflict resolution, which in turn requires political goodwill from the part of policymakers of the states of the sub-region.

The often unhealthy relations and the frequent shift of alignment and realignment of forces in the Horn have made it difficult for effective regional 
institutions of cooperation for security and development to emerge and mature. The Inter-Governmental Authority on Drought and Development (IGADD), the sub-regional organization that was established in 1986 for coordinating the member states' policies mainly on environmental issues. As it could not play a significant role in bringing about the benefits of regionalism to the sub-region, IGADD was restructured in 1996, when there was the sprit of cooperation among the states of the Horn. The invigorated organization is to serve as a regional security organization, renamed the 'Inter-Governmental Authority on Development (IGAD). Cognizant of the danger of violent local conflicts with regional spillovereffect, IGAD the member states restructured the organization and gave it expanded mandate thereby making political, security, humanitarian, and economic affairs its priority areas.

However, the reversal in the pattern of regional inter-state politics dashed the organization's hope to move the sub-region up on the security ladder. The new cycle of mistrust as well as rivalries for regional leadership that resurfaced in the second half of the 1990s among the Horn states dashed the hope to resolve conflicts and promote inter-state cooperation in the interest of mutual security. Conflicts and shifting alliance formations have incapacitated IGAD to deal with issues of security and development. Encountered credibility gap due to its member states' partisan posture, the role IGAD could play to resolve conflicts - both intrastate and inter-state - in the Horn of Africa is very marginal.

This is not to dismiss the role of IGAD, but to underscore that it needs to be empowered and to have a new vision to realize its mission as a regional security organization. Put differently, empowered IGAD acting as a neutral regional mediator - not as a partial power broker -can build and promote its credibility and legitimacy. As IGAD, the inter-governmental agency, is vulnerable to political obstacles and, thus, unable to deal with conflicts and coordinate regional security policies of its member states measures like professionalizing its staff, giving it necessary autonomy to operate outside of state sovereignty, and bringing the influence of the civil society into its operations by putting in place institutions like a regional parliament are important tasks ahead.

There are several justifications why cooperation is necessary in the Horn (Medhane, 2004; Tafesse, 1998). As the root causes of conflicts in the sub-region are interlinked, operating in a regional framework will have economic, political, social, and environmental security benefits (Markakis, 1998). Regional cooperation enables coordinated and regulated use of shared resources (Medhane, 2004). Unregulated utilization of shared resources does not only cause and perpetuate conflicts, but worsens their devastating consequences. In the light of this, institutionalized regional cooperation would help avoid existing psycho- 
political barrier and provide confidence-building measures in intra-state and interstate relations.

Even though the state as the dominant actor in international relations is no longer sacrosanct in light of the bourgeoning role of non-state actors, it still remains the major actor. The sovereign state commands the power of allocating/distributing national resources. Owing to this fact, it remains to be the main organizing actor both at the national and international levels. It also will continue to play crucial role even in the performance of global organizations in the foreseeable future. The role of the state in the Horn of Africa sub-system is not an exception. Given this universal role of the state, achievement of peace and security in the Horn, at both local and regional levels, requires change in the modus operandi of state leaders in the sub-region. Both wielders of state power and those who aspire for office must convince themselves of the need to emphasize on peace, security and economic development at both domestic and regional levels. The international community also has to play positive role in this regard. In short, institutionalizing procedures for fair-share of resources (power and wealth) in the interest of peace within and between states can alter the hitherto existing unhealthy nature of state-state and state-society relations in the Horn of Africa.

\section{Concluding Remarks}

This paper has tried to underline that an incorrect understanding of the root causes of conflict leads to unrealistic conflict resolution and post-conflict peace management strategies in the Horn of Africa. The failure of the U.S. led-UN mission in Somalia (UNISOM) in the early 1990s and the border demarcation efforts to end the Ethio-Eritrean "border dispute" are the prime examples of this. The UNISOM failed to meet its intended mission because of its lack of knowledge of how politics is organized and played out in Somalia. Efforts at EthiopianEritrean border demarcation could not succeed largely because of incorrect understanding of the root cause of the conflict that erupted into open warfare between these sisterly countries in May 1998. In view of this even if the borderdemarcation process were succeeded, it would not bring about normalization of relations between the two countries. As long as one of the parties (Eritrea in this case) would feel its prime intention has not been met, and consider itself as a "loser" the problem would remain unresolved.

Another disturbing concern about the conflict in the Horn is the prevailing divergent administrative structures and political organizations of the states of the sub-region. Ethiopia has adopted ethnicity as a basis for state and political party organization. While Eritrea is a de jure one-party state, in Djibouti, the country that apparently has accepted the principle of multiparty democracy, the ethnic-Afar still feels political and economic marginalization. In Kenya the tendency is to 
marginalize political parties of stronger ethnic groups in favor of smaller ones with a view not to jeopardize the primacy of the country's ruling party (Wanjohi, 1997). While Somalia is still with an unclear future, Sudan has witnessed disintegration with the South Sudan becoming an independent state while still leaving analysts with regard to how the North-South relations would proceed in the future.

This paper argued that political dynamics are the root causes of conflict and insecurity in the Horn of Africa. It also argued that the way the cause of the conflicts is understood determines the mechanisms to be put in place for conflict resolution and post-conflict peace management. This calls for a shopping-list of policy measures necessary to rise to the challenges of the problem of security. The following scenarios are suggested to this end.

\section{Scenario 1}

The conventional/traditional approach to the study of security in the Horn subregion is dominated, by what I may call 'layered approach', i.e. to analyze the issue of conflict at different levels that generally tend to explain that conflicts occur horizontally. Put differently, the traditional explanations of the conflict in the sub-region tend to be periphery versus periphery approach, emphasizing issues of identity markers such as religion, region, and ethnicity. Such an approach to conflict study in the final analysis makes the state out of the scene. If the problem of security is to be addressed it is imperative to correct this approach and emphasize on the centrality of the role the state in conflicts.

\section{Scenario 2}

Owing to the centrality of the role of the state in conflict democratization of the state-society relations is imperative. The central argument of this paper is that security and democracy are closely intertwined. Conflict is the phenomenon that emanates from lack of good governance; that is, inter alia, lack of popular participation in the process of decision making (Olufemi 2000: 227), and lack of accountability of political power holders for their policy commission and omission. Hence, to efficiently rise to the challenges of the problem of conflict and security in the Horn is an urgent need for democratizing the politics of the region, at both national and regional levels.

\section{Scenario 3}

It must be noted that the primacy of security can not be over-emphasized owing to the fact that without security it is not possible for both political and economic actors to plan to undertake any activity of national and regional importance. The myriad of negative impacts conflicts pose at all stages where they are played is obvious. They divert policymakers' attention, their time and energy and, more 
importantly, the economic resources of the concerned nation or nations from development drives. At the same time, particularly in sub-regions like the Horn, conflicts spill over from one level to the other, like a cyclone which has no regard for frontiers, so to say. On the other hand, the states in the Horn, although they share socio-cultural values emanating from centuries-old interactions, do not have shared political values and culture. In view of this, the need for democratization, suggested in Scenario 2 above, will avoid the bad government-to-government relations and help bring the desired shared political values to the fore. This will no doubt make it possible for policy harmonization to collectively rise to the problem of security in the Horn sub-region.

\section{Scenario 4}

Rising to the problem of security also demands mapping out a systematic and consistent program of policy formulation, analysis and action at individual state level and collectively at the regional level. The Intergovernmental Authority for Development (IGAD) can be suggested as in charge for this task. And yet IGAD as an institution in place to deal with the issue of conflict and security mobilizing its security architecture is seriously constrained by the nature of politics in the Horn. In the first place, IGAD does not command requisite credibility from some member states: for instance, Eritrea has withdrawn its membership, Somalia is a failed state, and Somaliland is not a member state owing to the fact that it is still not given recognition. In addition, financial and technical resources available at the disposal of the Intergovernmental Authority are meager. IGAD also does not have a regional peacekeeping force under its own command. This again leaves the ball at the gate of member states. This means, there is a need for the political goodwill of the active member states to empower this regional institution politically, militarily and financially.

\section{Scenario 5}

Last but by no means the least, intra and inter-state conflicts in the Horn are also fed on and fueled by many forces and factors. Cross-border insurgency, terrorist activities, and illicit arms and drug trafficking have dangerous local and regional impact. While there is the need for concerted regional effort to curb this, once again Africa in general and the Horn sub-region in particular has also become the chess-board of different foreign powers. As this will create additional schisms in intra-state and inter-state politics, it is imperative for the Horn states to collectively design policies on how to deal with this new-turn involvement of foreign powers competing for the untapped resources of the region for their narrow interests. What must be emphasized here is competition among the states in the region for incautious partnership with these foreign powers coming from different corners of 
the world might play into the hands of foreign companies that want increasingly generous incentives such as, for example, substantial tax reductions (Notshulwana 2000: 175, in Junadu). This inevitably hurts economically this region of protracted poverty and politically erodes further regime legitimacy already based on narrow/shaky grounds.

\section{References}

Adewoye, Omonyi. 2000. "Leadership and the Dynamics of reform in Africa," in, Haroub Othman (ed.), Reflections on Leadership in Africa: Forty Years After Independence. Dar Es Salam and Brussels, np.

Amare Tekle. 1996. "International Relations in the Horn of Africa 1991-96" in Review of African Political Economy. Vol. 23, No.70.

Asnake Kefale. 2009. Federalism and ethnic conflict in Ethiopia: A comparative study of Somali and Benishangul-Gumuz Regions. Ph.D. Dissertation. University of Leiden, The Netherlands

Cliffe, Lionel. 1999. "Regional Dimensions of Conflict in the Horn of Africa”, In: Third World Quarterly, Vol. 20, Issue 1, start page 89. Carfax Publications Campony. Feb. 1999.

Deng, Francis M.; Kimaro, Sadikiel; et.al (eds.), 1996. Sovereignty as Responsibility: Conflict Management in Africa. Washington D.C.. The Brookings Institution.

Elsenhans, Hartmut. 1993. "Germany's Role in the Arab World and Intensified European Integration”, In: Teaching Politics, Vol. 19, Nos. 3\&4, 1993. University of Delhi. 1996. The State, Class, and Development. New Delhi, Radiant Publishers. Horn of Africa Bulletin, February, 1998.

Jinadu, L. Adele. 2000. "Introduction: The Dialectics of Democracy, Development, Peace and Security in Africa,” in, Jinadu, L. Adele (ed.), The Political Economy of Peace and Security in Africa: Ethnocultural and Economic Perspectives. Harare: AAPS Books.

Khadiagala, Gilbert M. and Terrence Lyons (ed.). 2001. African Foreign Policies: Power \& Process. Lynne Rienner publishers, Boulder and London. Kanet, Roger E.(ed.). 1998. Resolving Regional Conflicts. Illinois, USA.

Kiplagat, Bethuel A. 2000. "Conflict Interlinkages in the Horn: Spillover Effect of War and Peace", Background Paper, Prepared for "The Horn of Africa: Between Post-War Reconstruction and Fragmentation” An Expert Workshop (SEF Policy Forum on Regional Conflict Management), held by the Development and Peace Foundation (SEF) in collaboration with the 
Katholisch - Soziales Institut (KSI) from 29 August - 2 September 2000 in bad Honnef.

Laitin, David D. and Siad S. Samatar. 1984. 'Somalia and the World Economy”, in Review of African Political Economy, No 30, September 1984.

Mangen, Stephen P. (ed.) 2001. Spanish Society After Franco: Regime Transition and the Welfare State. New York: Palgrave

Markakis, John. 1998. Resource Conflict in the Horn of Africa. London, Sage Publications.

. 1994. "Ethnic Conflict and the State in the Horn of Africa", In: Fukui, K. \& Markakis, John (eds.), 1994. Ethnicity and Conflict in the Horn of Africa. London. James Currey Ltd.

Medhane Tadesse, 2004. Turning Conflicts to Cooperation. Friedrich-EbertStieftung, Ethiopia Office, Addis Ababa. . 2002. Al-ittihad: Political Islam and Black Economy in Somalia. Religion, Money, Clan and the Struggle for Supremacy Over Somalia. Addis Ababa. Mega Printing Enterprise.

Mesfin Wolde-Mariam. 1999. The Horn of Africa Conflict and Poverty

Michael Lund and Wendy Betts, “The Horn of Africa: In Search of Regionalism”, www.euconflict.org; European Platform for Conflict Prevention and Transformation website.

Notshulwana, Mxolisi. 2000. "The Political Economy of Regional Integration in Southern Africa,” in, Jinadu, L. Adele (ed.), 2000. The Political Economy of Peace and Security in Africa: Ethnocultural and Economic Perspectives. Harare: AAPS Books.

Olufemi, Kola. 2000. "Social and National Questions: The Crisis of State in Africa”, in,

Jinadu, L. Adele (ed.) 2000. The Political Economy of Peace and Security in Africa: Ethnocultural and Economic Perspectives. Harare: AAPS Books.

Oyugi, Walter O. 2001. "Politicized Ethnic Conflict in Kenya: A Periodic Phenomenon", in Proceedings of the Conference on African Conflicts: Their Management, Resolution and Post-Conflict Reconstruction held at the United Nations Economic Commission for Africa, 13-15 September 2000, organized by Development Policy Management Forum (DPMF)

Project Ploughshares, Military Profiles 1998-Horn of Africa Countries, www.Ploughshares.Ca/, Accessed, 19/11/2001.

Samatar, A.I. 1988. Socialist Somalia: Rhetoric and Reality. London. Zed Books Ltd.

Sosina Ayalew. 1994. "Ethiopia’s Foreign Policy,” in, Ethioscope, a Quarterly Magazine.Addis Ababa: The Ministry of Foreign Affairs (Ethiopia). 
Tafesse Olika. 1998. "Resources, Conflict, and the Need for Cooperation in the Horn of Africa," in, Ethioscope, a Quarterly Magazine published by the Ministry of Foreign Affairs of the Federal Democratic Republic of Ethiopia.

Tekeste Negash \& Kjetil Tronvoll. 2000. Brothers at War: Making Sense of the Eritrean-Ethiopian War. Oxford. James Currey ltd.

Touval, Saadia. 1963. Somali Nationalism: International Politics and the Drive for Unity in the Horn of Africa, Cambridge.

Wanjohi, Nick G. 1997. Political Parties in Kenya: Formation, Policies and Manifestoes. Views Media, Nairobi 